THE influence of roxithromycin (RXM) on the expression of co-stimulatory molecules, CD40, CD80 and CD86, was examined in vivo. When BALB/c mice were immunized intraperitoneally with two doses of dinitrophenylated ovalbum in (DNP-OVA) at 1 week in tervals, intraperitoneal administration of RXM at $250 \mu \mathrm{g} / \mathrm{kg}$ once a day for 14 days strongly suppressed IgE contents in sera obtained from mice 22 days after the first immunization. In addition, RXM treatment of mice suppressed endogenous IL-4 contents in aqueous spleen extracts, which were enhanced by DNPOVA im munization. We next examined the influence of RXM on co-stimulatory molecule expression on splenic lymphocytes. RXM treatment of the immunized mice caused suppression of CD40 expression, but this treatment did not affect CD80 and CD86 expression.

Key words: Roxithromycin, CD40, Suppression, Dintrophenylated ovalbumin, Immunization, Mouse, In vivo

\section{Suppressive activity of a macrolide antibiotic, roxithromycin on co-stimulatory molecule expression on mouse splenocytes in vivo}

\author{
K. Kawazu, ${ }^{1}$ M. Kurokawa, ${ }^{1,{ }^{*}, \mathrm{CA}}$ K. Asano, ${ }^{2}$ A. Mita ${ }^{3}$ \\ and $\mathrm{M}$. Adachi ${ }^{1}$
}

${ }^{1}$ First Department of Internal Medicine, ${ }^{2}$ Department of Physiology, Showa University School of Medicine, and ${ }^{3}$ Division of Immunology, Research Centre for Medical Sciences, Showa University Hospital, 1-5-8 Hatanodai, Shinagawa-ku, Tokyo 142-8555, Japan

* Department of Internal Medicine, Kikuna Memorial Hospital, 4-4-27 Kikuna, Kouhoku-ku, Yokohama 222-0011, Japan

CA,* Corresponding Author and Address
Tel: $(+81) 454027111$
Fax: $(+81) 454027331$

\section{Introduction}

Administration of macrolide antibiotics such as erythromycin and troleandomycin can favourably modify the clinical status of patients with inflammatory diseases. ${ }^{1-3}$ Although investigation of the mechanisms of improvement has suggested that it is not due to anti-microbiological effects of the drugs, the precise mechanisms are not well understood. ${ }^{4-6}$

We have demonstrated that oral administration of roxithromycin (RXM) once a day for 21 days could suppress the ability of lymphocytes to produce several types of inflammatory cytokines such as IL-1, IL-3 and IL-5 in response to mitogenic stimulation in vivo and in vitro. ${ }^{6-9}$ Subsequently, Eyrand ${ }^{10}$ and Forsgre ${ }^{11}$ have reported that macrolide antibiotics such as erythromycin, troleandomycin and RXM inhibited chemotax is and generation of inflammatory mediators from polymorphonuclear leukocytes when the cells were cultured in vitro in the presence of macrolides.

It is generally accepted that antigen-specific immune responses are initiated after the collaboration of T-cells with antigen presenting cells (APC). ${ }^{12}$ Recently, it has been found that an optimal T-cell activation requires another cell-to-cell interaction. ${ }^{12,13}$ The first signal transduction is due to the interaction between T-cell receptor and major histocompatibility complex class II molecule with antigenic determinant. The second signal is provided by the direct contacts of co-stimulatory molecules on T-cells with their ligands on APC. ${ }^{13,14}$ The signal through the binding of CD28/CTLA4 on T cells with its ligands, CD80 and CD86 on APC is a crucial co-stimulatory pathway. ${ }^{12-14}$ Furthermore, engagement of the B-cell marker CD40 by its ligand CD40 L is also recognized to play an important role in T-cell-dependent isotype sw itching to $\operatorname{IgE}^{14,15}$

There is much evidence that expression of the costimulatory molecules CD40, CD80 and CD86 on peripheral blood leukocytes from patients with inflammatory diseases was upregulated compared with normal subjects, ${ }^{16-18}$ suggesting the importance of these molecules in the induction and the development of the diseases. The refore, the present study was undertaken to answer the unresolved questions regarding the favourable effects of macrolide antibiotics on inflammatory diseases by examining the influences of RXM on expression of co-stimulatory molecules in mice. 


\section{Materials and Methods}

\section{Mice}

BALB/c male mice, 5 weeks of age, were purchased from Charles River Japan Inc. (Atsugi, Japan).

\section{Immunization}

BALB/c mice were immunized by intraperitoneal injection of $5.0 \mu \mathrm{g} / \mathrm{ml}$ of dinitrophenylated ovalbumin (DNP-OVA) absorbed on $4 \mathrm{mg} \mathrm{Al}(\mathrm{OH})_{3}$, and boosted intraperitone ally with the same dose of antigen 7 days later.

\section{Drugs and treatment}

RXM was kindly donated by EISAI Co. Ltd (Tokyo, Japan) as a water insoluble pure powder. The agent was dissolved in methyl alcohol at $50 \mathrm{mg} / \mathrm{ml}$ and diluted with normal saline so as to give $1.0 \mathrm{mg} / \mathrm{ml}$. This solution was then sterilized by passing through a $0.22 \mu \mathrm{m}$ filter and stored at $4^{\circ} \mathrm{C}$ until used. The immunized mice were given $250 \mu \mathrm{g} / \mathrm{kg} /$ day of RXM intraperitoneally for 14 days starting 7 days after the first immunization and the non-immunized mice injected with the same dose of RXM for 2 weeks. Since our previous reports have shown that administration of $2 \%$ alcohol did not show any adverse effects on mouse immune responses, ${ }^{6,7,9}$ the control mice received saline in the same route.

\section{Assay for serum total $\lg \mathrm{E}$}

The blood was obtained from the mice by cardiac puncture under ether anesthesia 22 days after the first immunization. After clotting, the serum was obtained and total serum IgE levels were measured by mouse IgE enzyme immunoassay kits (YAMASA Co. Ltd, Chiba, Japan) according to the manufacturer's recommended procedures. The assay was performed in duplicate and the results were expressed as the mean $\mathrm{ng} / \mathrm{ml} \pm \mathrm{SD}$ of five individual mice.

\section{Preparation of aqueous spleen extracts}

The spleen was removed from mice killed under ether anesthesia and stored in ice-cold PBS until processed. The organ was homogenized in $0.5 \mathrm{ml}$ PBS in an icecold water bath for $3 \mathrm{~min}$ using a glass tissue homogenizer. The supernatant was obtained by centrifugation of the homogenized materials at $10000 \mathrm{~g}$ for $1 \mathrm{~h}$ at $4^{\circ} \mathrm{C}$ and used for aqueous spleen extract.

\section{Assay for IL-4}

IL-4 concentration in aqueous spleen extract was assayed by commercially available mouse IL-4 ELISA kit (GENZYME Corp., Cambridge, MA, USA) accord- ing to the manufacturer's recommended procedures. The ELISA was done in duplicate and the results were expressed as the mean $\mathrm{pg} / \mathrm{ml} \pm \mathrm{SD}$ of five individual mice.

\section{Preparation of spleen cell suspension}

The spleen was removed from mice killed under ether anesthesia and pressed through a 60 gauge steel mesh to give a single cell suspension. After centrifugation at 1000 r.p.m. for $10 \mathrm{~min}$ at $4^{\circ} \mathrm{C}$, the pelleted cells were treated with $0.15 \mathrm{M}$ Tris $-0.75 \% \mathrm{NH}_{4} \mathrm{Cl}$ solution for $10 \mathrm{~min}$ to lyse red blood cells. After filtering through a 200 gauge steel mesh, the residual cells were washed three times and suspended in PBS at a concentration of $1 \times 10^{6}$ cells $/ \mathrm{ml}$.

\section{Monoclonal antibodies (mAbs) and flow cytometry}

The mAbs used in this study were anti-mouse CD16/ CD32 mAb, fluorescein isothiocyanate (FITC)-conjugated anti-mouse CD40 mAb (hamster IgM), phycoerythrin (PE)-conjugated anti-mouse CD80 mAb (hamster IgG), FITC-conjugated anti-mouse CD86 mAb (rat IgG2a). They were purchased from PharMingen (San Diego, CA, USA). To block nonspecific adherence of antibodies to murine $F_{c}$ receptors, spleen cells $\left(1 \times 10^{6}\right)$ were incubated with $1.0 \mu \mathrm{g}$ of anti-mouse CD16/CD32 $\mathrm{mAb}$ for $5 \mathrm{~min}$ at $4^{\circ} \mathrm{C}$, washed, and then labelled with either anti-mouse CD80, CD86, or CD40 for $20 \mathrm{~min}$ in an ice-cold water bath. After washing once, fluorescent staining was analysed immediately by flow cytometry on a FACScan (Becton Dickinson, Mountain View, CA, USA). The fluorescent intensity of cells was expressed as the mean \pm SD of four different experiments. Spleen cells were also stained with monoclonal immunoglobulin isotype standards (FITC-conjugated hamster $\operatorname{IgM}$ against trinitrophenol and PE-conjugated hamste $\mathrm{IgG}$ against keyhole limpet haemocyanin) purchased from PharMingen, and fluorescent staining was analysed in a similar manner.

\section{Statistical analysis}

The statistical significance of the difference in the mean values between two groups was analysed by Mann-Whitney $U$ test.

\section{Results}

\section{Influence of RXM on IgE and IL-4 production} in mice

The first set of experiments was carried out to examine the influence of RXM on $\operatorname{IgE}$ and IL-4 production in immunized mice. As show $\mathrm{n}$ in Table 1 , 
Table 1. Influence of roxithromycin (RXM) on IgE production and IL-4 appearance in BALB/c mice immunized with DNP-OVA mixed with $\mathrm{Al}(\mathrm{OH})_{3}$

\begin{tabular}{lccc}
\hline Type of mice examined & Treatment & $\begin{array}{c}\text { IgE levels } \\
\text { (ng/ml } \pm \text { SD) }\end{array}$ & $\begin{array}{c}\text { IL-4 levels } \\
\text { (pg/ml } \pm \text { SD) }\end{array}$ \\
\hline Non-immunized & Saline & $3.9 \pm 1.1$ & $18.8 \pm 3.5$ \\
Immunized & RXM & $4.0 \pm 0.1^{*}$ & $14.1 \pm 6.0^{*}$ \\
& Saline & $223.8 \pm 14.3$ & $81.5 \pm 9.7$ \\
& RXM & $72.4 \pm 6.3^{* *}$ & $31.5 \pm 5.7^{* *}$ \\
\hline
\end{tabular}

Each result was expressed as the mean \pm SD of five individual mice.

* Not significant when compared with saline-treated mice $(P>0.05)$.

** Significant when compared with saline-treated mice $(P<0.001)$.

RXM treatment of non-immunized mice did not caused changes of IgE and IL-4 levels: IgE and IL-4 contents in sera and aqueous spleen extracts from RXM-treated, non-immunized mice were nearly identical to those from saline-treated, non-immunized mice $(P>0.05)$. On the other hand, RXM treatment caused significant suppression of $\operatorname{IgE}$ and IL-4 contents in sera and extracts, which were enhanced by DNP-OVA immunization. IgE levels in sera from saline-treated, immunized mice were significantly decreased from $223.8 \pm 14.3 \mathrm{ng} / \mathrm{ml}$ to $72.4 \pm 6.3 \mathrm{ng} / \mathrm{ml}$ by $\mathrm{RXM}$ treatment $(P<0.001)$. IL-4 levels in the extracts were also decreased from $81.5 \pm 9.7 \mathrm{pg} / \mathrm{ml}$ to $31.5 \pm 5.7 \mathrm{pg} /$ $\mathrm{ml}$ by RXM treatment $(P<0.001)$.

\section{Influence of RXM treatment on co-stimulatory molecule expression on spleen cells in vivo}

This study was designed to examine the influences of RXM on various profiles of CD40, CD80 and CD86 to be expressed on B-lymphocytes. In flow cytometry on FACScan, we gated and analysed on the lymphocyte position/population of scattered dots of spleen cells in the display of computer. Figure 1 shows one typical profile among results obtained in four experiments of mice immunized and non-immunized by DNP-OVA antigen. RXM treatment of non-immunized mice scarcely affected the expression profiles of the CD molecules on the gated splenic lymphocytes (Fig. 1, left). In immunized mice, however, RXM exerted remarkable suppression of CD40 molecule expression on the gated lymphocyte population, which was enhanced by DNP-OVA antigen (Fig. 1, right). The fluorescent intensity of splenic lymphocytes prepared from saline-treated mice was $670.8 \pm 89.65$ and that from RXM-treated mice was $344.56 \pm 52.48$. On the other hand, expression of CD80 and CD86 molecules was not influenced by the 2 -week treatments with RXM (Fig. 1, right).

\section{Discussion}

Several studies have show $n$ that macrolide antibiotics can favourably influence the clinical condition of certain patients with allergic diseases. ${ }^{1-3}$ Naturally, much efforts have been done to understand the mechanisms by which macrolide antibiotics modify the clinical status of allergic diseases. ${ }^{4-7,9-11}$ However, the precise mechanisms are not well defined.

There is much evidence that allergic diseases are caused by $\operatorname{IgE}$ antibodies against specific allergens. Ishizaka has described that the prevention or suppression of IgE antibody formation against allergens might be one of fundamental treatment of allergic diseases. ${ }^{19}$ Therefore, we examined the influence of RXM on IgE production in vivo. The results obtained (Table 1) clearly demonstrate that 2 -week treatments with RXM could suppress IgE production in actively sensitized mice.

Previously, we found that RXM significantly suppressed the enhancement of ${ }^{3} \mathrm{H}$-thymidine uptake by human peripheral blood leukocytes induced by in vitro stimulation with T-cell mitogen (Concanavalin A), but not with B-cell mitogens. ${ }^{7}$ We also reported the suppressive activity of RXM on the ability of T-cells to produce several types of cytokines including IL-5 in vitro and in vivo. ${ }^{6}$ Although experimental and clinical data show that IgE synthesis in B-cells is dependent on a complex process involving several cellular and molecular interactions, ${ }^{15,20-22}$ there is a established concept that IL-4 secreted by T-cells, especially Th2 type helper T-cells, is the most important cytokine for IgE generation. Taken together, the present results (Table 1 ) suggest that RXM treatment inhibits in vivo IL-4 secretion in response to DNPOVA immunization and results in suppression of $\mathrm{IgE}$ levels in immunized mice. This suggestion is supported by the finding that treatment of mice with RXM significantly inhibits endogenous IL-4 levels, which were enhanced by DNP-OVA immunization.

There are circumstantial evidences that allergenspecific Th2 type helper T-cells play a pivotal role in the induction and development of many allergic diseases. ${ }^{23-25}$ And also, optimal T-cell activation is recognized to require not only interaction between antigen peptide bound to MHC molecules of APC and the T-cell receptor, but also additional signals, socalled co-stimulation. A number of recent reports have shown that ligation of CD28 on T-cells and CD80 or CD86 on APC is essential for activation of Th2 type 

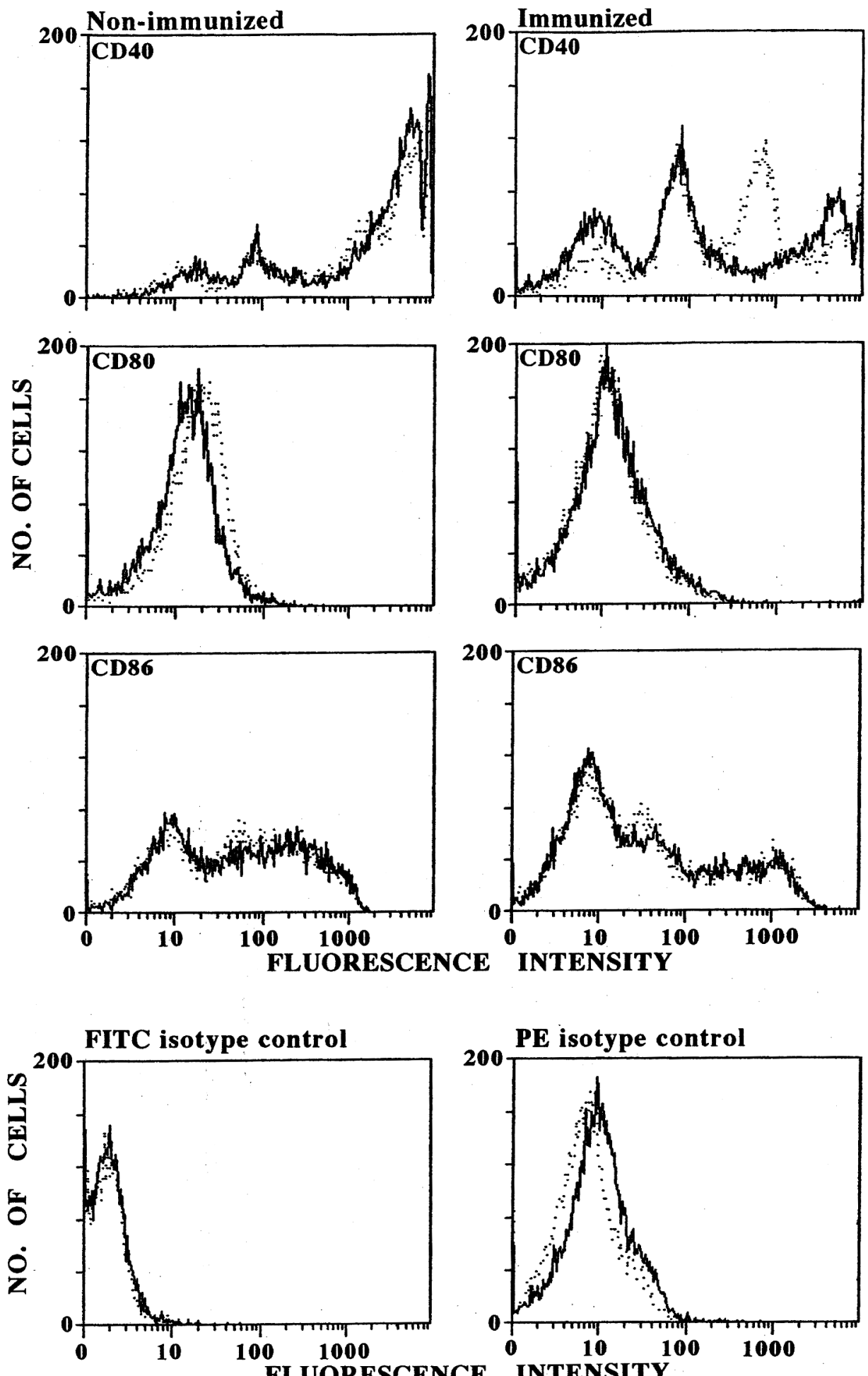

FIG. 1. Influence of roxithromycin on expression of co-stimulatory molecules on spleen cells prepared from BALB/c mice. Determination was done $24 \mathrm{~h}$ after treatment. The data were analysed by overlay histograms (FL-1 or FL-2) of splenocyte population gated on lymphocyte position in scattered dots (FSC and SSC). The figure shows a representative expression profile of results obtained in four different experiments. […], saline-treated control mice; [-], RXM-treated mice.

helper T-cell and production of IL-4. ${ }^{26,27}$ Additionally, interaction between CD40 on activated B-cells and its ligand CD40L on T-cells has been reported as an important co-stimulatory signal for switch recombination to $\operatorname{IgE}$ synthesis in the presence of $\mathrm{IL}-4$.
Therefore, we next examined the influence of RXM on CD40, CD80 and CD86 expression on spleen cells. The present results clearly showed that RXM treatment of mice strongly suppressed the expression of CD40 co-stimulatory molecule enhanced by DNP-OVA 
immunization, suggesting that protective effect of RXM against IgE hyper-production is associated with its suppressive effect on co-stimulatory molecule expression.

Although the present study may provide possible mechanisms by which macrolide antibiotics can modify favourably the clinical condition of allergic diseases, more in-depth analyses are needed to clarify the mode of action of the agents in the diseases. For example, there are research subjects concerning CD4 vs. CD8 expression in thymus and lymph node, and $\operatorname{sg} D$ vs. $\operatorname{sg} M$ expression in spleen to show the existence of mature lymphocytes. In addition, the suppression mechanisms of RXM regarding syntheses of proteins such as IL-4 and CD40 molecules examined here are not clear at present. How ever, FK506 and rapamycin, macrolide antibiotics, exert their immunosuppressive effects by formation of complex between immunophilin and agents which can inhibit gene transcription. ${ }^{28,29}$ It is possible that RXM binds to immunophilin, intracellular binding protein, and the complexes interferes gene transcription, resulting in inhibition of protein synthesis. Another experiments are also needed to clarify this point.

\section{References}

1. Itkin IH, Menzel ML. The use of antibiotic substances in the treatment of asthma. J Allergy 1970; 45: 146-162.

2. Spector SL, Katz FH, Farr RS. Troleandomycin: effectiveness in steroiddependent asthma and bronchitis. J Allergy Clin Immunol 1974; 54: 375-379.

3. Miyatake H, Taki F, Taniguchi H, et al. Erythromycin reduces the severity of bronchial hyperresponsiveness in asthma. Chest 1991; 99: 670-673.

4. Miyachi Y, Yoshida A, Imamura S, Niwa Y. Effect of antibiotics on generation of reactive oxygen species. J Invest Dermatol 1986; 86: 449-453.

5. Plew ig G, Schopf E. Anti-inflammatory effects of antimocrobial agents: an in vivo study. J Invest Dermatol 1975; 65: 532-536.

6. Konno S, Adachi M, Asano K, Okamoto K, Takahashi T. Anti-allergic activity of roxithromycin: inhibition of interleukin -5 production from mouse T lymphocytes. Life Sci 1993; 52: 25-30.

7. Konno S, Adachi M, Asano K, et al. Influence of roxithromycin on cellmediated immune responses. Life Sci 1992; 51: 107-112.

8. Konno S, Adachi M, Asano K, Okamoto K, Takahashi T. Inhibition of human Tlymphocyte activation by macrolide antibiotic, roxithromycin. Life Sci 1992; 51: 231-236.
9. Konno S, Asano K, Kurokawa M, et al. Antiasthmatic activity of a macrolide antibiotic, roxithromycin: analysis of possible mechanisms in vitro and in vivo. Int Arch Allergy Immunol 1994; 105: $308-316$.

10. Eyrand A, Descotes J, Lombard JY, Laschi-Loquerie A, Tachon P. Effects of erythromycin, josamycin and spiramycin on rat polymorphonuclear leukocyte chemotaxis. Chemotherapy 1986; 32: 379-382.

11. Forsgren A, Schmeling D. Effect of antibiotics on chemotax is of human leukocytes. Antimicrob Agents Chemother 1977; 11: 580-584.

12. Lenschow DJ, Walnus TL, Bluestone JA. CD28/B7 system of T cell costimulation. Annu Rev Immunol 1996; 14: 233-258.

13. Robinson DS. T cell costimulation: a potential therapeutic target in asthma? Clinical Exp Allergy 1998; 28: 788-790.

14. Marone G. Asthma: recent advances. Im munol Today 1998; 19: 5-9.

15. Worm M, Henz BM. Molecular regulation of human IgE synthesis. $J$ Mol Med 1997; 75: 440-447.

16. Hofer MF, Jirapongsananuruk O, Trumble A, Leung DYM. Upregulation of B7.2, but not B7.1, on B cells from patients with allergic asthma. J Allergy Clin Im munol 1998; 101: 96-102.

17. Jirapongsananuruk O, Hofer MF, Trumble AE, Norris DA, Leung DY. Enhanced expression of B7.2 (CD86) in patients with atopic dermatitis: a potential role in the modulation of $\operatorname{IgE}$ synthesis. J Im munol 1998; 160: 4622-4627.

18. Mark DA, Donovan CE, De Sanctis GT. Both CD80 and CD86 costimulatory molecules regulate allergic pulmonary inflammation. Int Immunol 1998; 10: 1647-1655.

19. Ishizaka K, Iwata M, Carini C, Katamura K, Takeuchi T. Antigen-specific factors in IgE regulation. In: Sorg C, ed. Cytokines Regulating the Allergic Response. Basel: Karger, 1989: 1-18

20. Jabara HH, Ahern D, Vercelli D, Geha RS. Hydrocortisone and IL-4 induce IgE isotype switching in human B cells. J Exp Med 1991; 147: $1557-1560$.

21. Kimata H. Differential effects on gangliosides on human $\operatorname{IgE}$ and $\operatorname{IgG} 4$ production. Eur J Immunol 1995; 25: 302-305.

22. Schatz DG, Oettinger MA, Schissel MS. V(D)J recombination: molecular biology and regulation. Ann Rev Imm unol 1992; 10: 359-383.

23. Hamid Q. Expression of mRNA for interleukin -5 in mucosal bronchial biopsies from asthma. J Clin Invest 1991; 87: 1541-1546.

24. Del Prete GF, 1993. Allergen exposure induces the activation of allergen-specific Th2 cells in airway mucosa of patients allergic respiratory disorders. Eur J Immunol 1993; 23: 1445-1449.

25. Ying S. Expression of IL-4 and IL-5 mRNA and protein product by CD4+ and CD8+ T cells, eosinophils, and mast cells in bronchial biopsies obtained from atopic and nonatopic (intrinsic) asthmatics. $J$ Immunol 1997; 158: 3539-3544.

26. Tsuyuki S, Tsuyuki J, Einsle K, KopfM, Coyle AJ. Costimulation through B7-2 (CD86) is required for the induction of a lung mucosal T helper cell 2 (TH2) immune response and altered airway responsiveness. J Exp Med 1997; 185: 1671-1679.

27. Van Neerven RJJ, Van De Pol MM, Van Der Zee JS, et al. Requirement of CD28-CD86 costimulation for allergen-specific $T$ cell proliferation and cytokine expression. Clin Exp Allergy 1998; 28: 808-816.

28. Dumont FJ, Staruch MJ, Koprak SL, Melino MR, Sigal NH. Distinct mechanisms of suppression of murine $T$ cell activation by the related macrolides FK-506 and rapamycin. J Im munol 1990; 144: 251-258.

29. Screiber SL, Crabtree GR. The mechanism of action of cyclosporin A and FK-506. Imm nol Today 1992; 13: 136-142.

\section{Received 7 February 2000; accepted 1 March 2000}




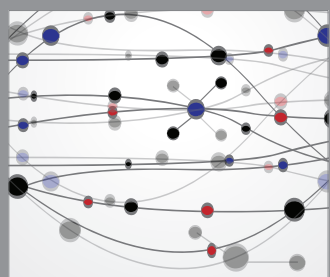

The Scientific World Journal
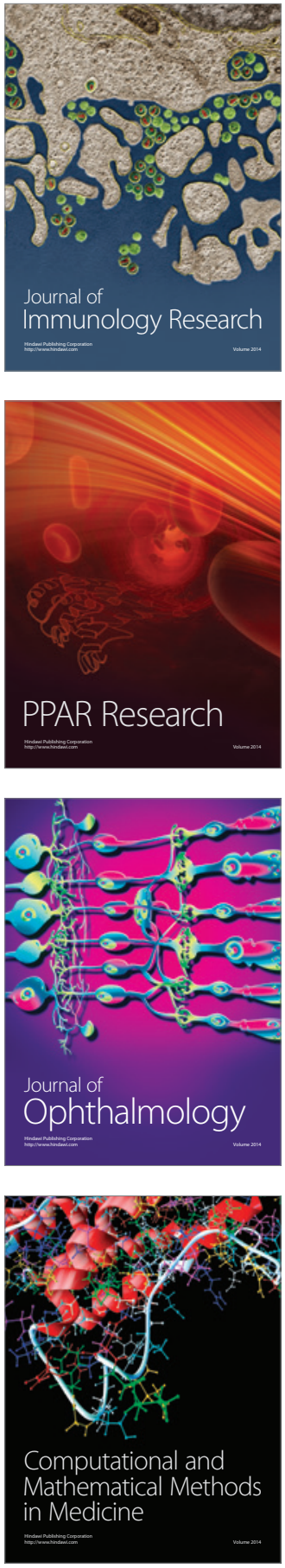

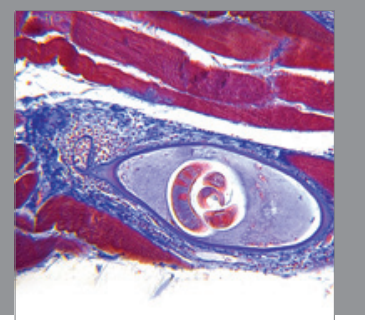

Gastroenterology

Research and Practice
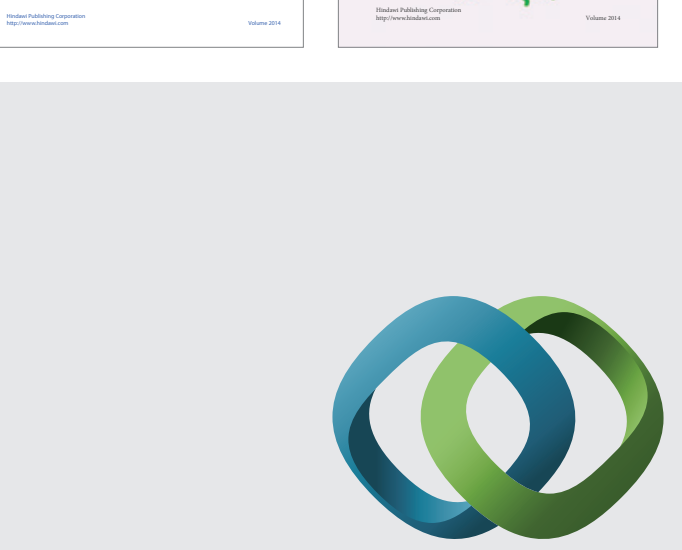

\section{Hindawi}

Submit your manuscripts at

http://www.hindawi.com
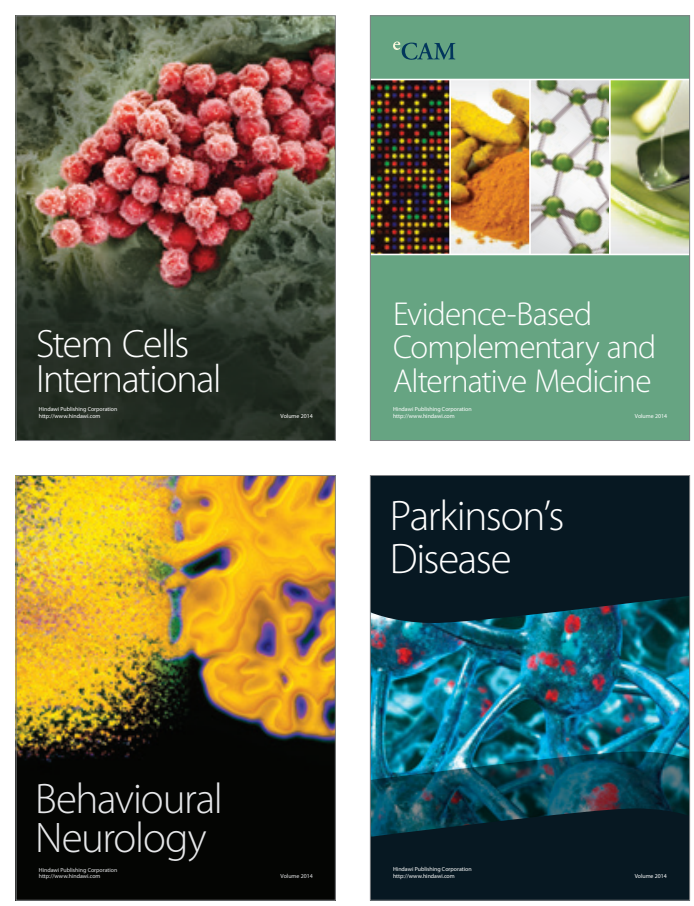

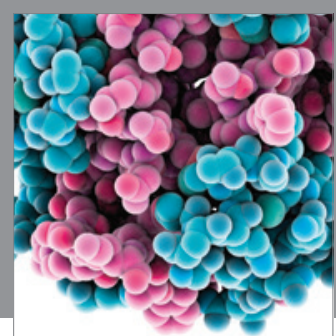

Journal of
Diabetes Research

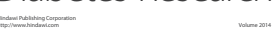

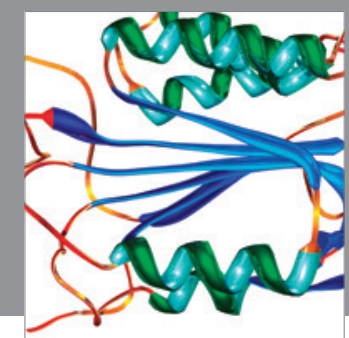

Disease Markers
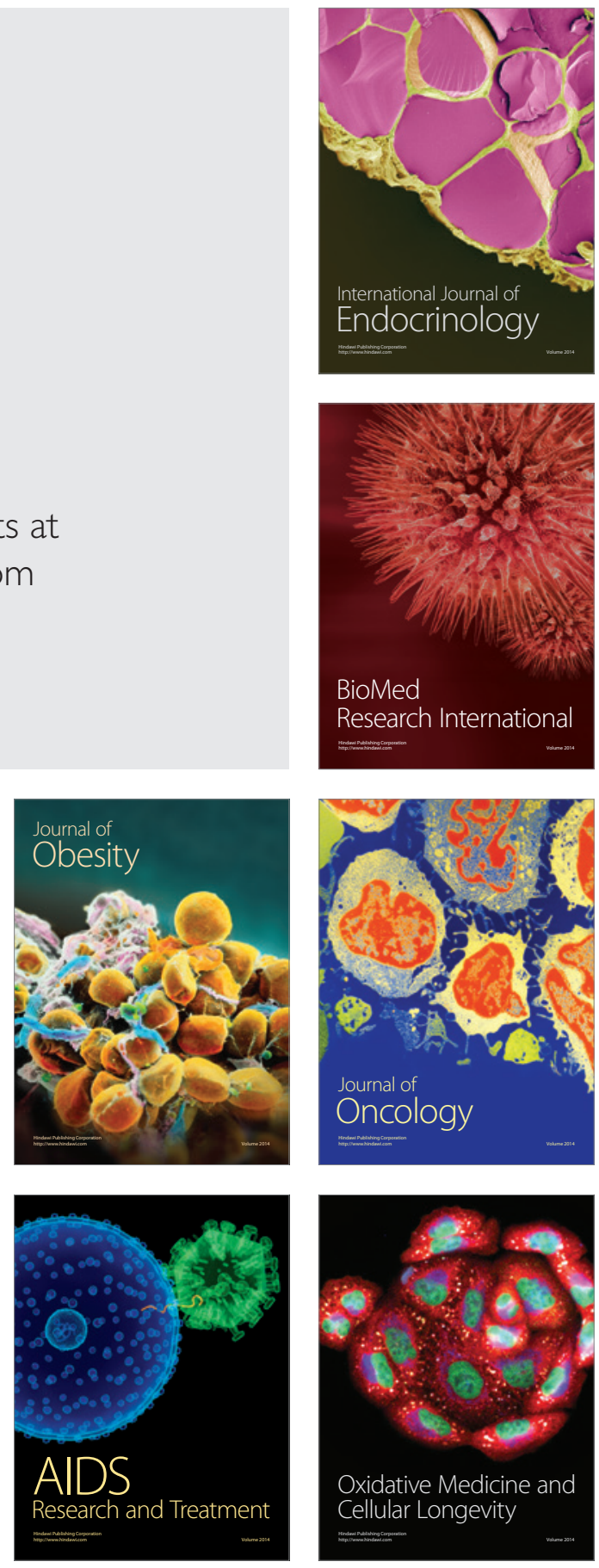